\title{
HADHARIAH : PENDEKATAN FILOSOFIS \\ MENGHADAPI PROBLEM DIKOTOMI ILMU \\ DALAM PENDIDIKAN ISLAM DI INDONESIA
}

\author{
BASINUN
}

\begin{abstract}
There are some Islamic education problems which generate dichotomy between religious sciences and general sciences. They are 1) weak vision; 2) emphasizing on individual piety causing technological backwardness; 3) scientific dichotomous; and 4) the mindset of normativedeductive. To overcome them, it is necessary to do a review of education reformation philosophically, epistemologically and theologically to realize the Islamic education in accordance with revelation guidance. As one of the efforts to improve Islamic education, this paper presents the philosophy of Hadhariyah (civilization philosophy) based on revelation demands. This Islamic study area divided into; the hadhara al-nash, hadhara al-'ilm, and hadhara al-falsafah. Philosophy of Hadhariyah emphasises the integrity between divinity (theocentric) dimension and humanitarian (anthropocentric) dimension, which are diametrically different from general philosophy that only grounded in human values. Hadhariyah philosophy recognizes something real, supernatural, physical, and metaphysical and it views the importance role of revelation, and moral values in education. Meanwhile, philosophy in general, limited by symptoms seen and captured by the senses empirically. Hence, Hadhariyah philosophy considers that acquisition of knowledge indicated to attain Allah SWT pleasure (science for mardhatillah) more than just knowledge for science.
\end{abstract}

Kata Kunci : Hadhariyah, Dikotomi Ilmu, Pendidikan Islam.

\section{A. PENDAHUluan}

Reformasi filsafat Islam saat ini sangat mendesak untuk dilakukan guna menciptakan kualitas pendidikan sebagaimana telah diarahkan oleh kitab suci. Ini harus dimulai dari filosofi aspek ontologis, aspek epistemologis dan aspek aksiologis, sebagai upaya untuk merespon tantangan pendidikan Islam saat ini. Masalah dikotomi antara ilmu agama dan ilmu umum menyebabkan degradasi perkembangan ilmu pengetahuan dan krisis metodologi ilmiah. Krisis di dunia pengetahuan 
dan pendidikan Islam saat ini menyebabkan tradisi ilmiah menjadi statis. Akhirnya, kehadiran pendidikan Islam belum sepenuhnya menunjukkan perannya dalam menciptakan peradaban maju, seperti masa kejayaan Islam pada abad 8-13 yang lalu. Abdullah menyatakan bahwa peradaban Islam adalah hasil dari proses perjuangan akumulasi penganut Islam yang berurusan dengan proses dialektik antara doktrin "normativitas" dari pewahyuan permanen dan "historisitas" pengalaman khalifah manusia di bumi yang selalu berubah. hari demi hari. ${ }^{1}$

Menurut paradigma religius humanis, untuk menciptakan kualitas pendidikan, harus mempertimbangkan akal sehat, individualisme menuju kemerdekaan, pendidikan pluralis, anti-dikotomi, semangat, fungsionalisme, pemukulan simbolisme, serta penghargaan dan sanksi. Sejalan dengan ini, Mas'ud menyatakan, "Pendidikan Islam sebagai tujuan, alat perubahan dan transformasi sosial harus diarahkan untuk mengakomodasi budaya lokal dan berorientasi masa depan, yang religius dan modern".2

Namun, masalah tetap ada dan orang-orang dari pendidikan Islam saat ini menurut Assegaf (2014) berasal dari empat hal berikut: 1) kurang visi; 2) penekanan pada kesalehan individu yang menyebabkan keterbelakangan teknologi; 3) dikotomi ilmiah; dan 4) pola pikir deduktif normatif. Hal-hal tersebut harus diatasi dengan masalah kekurangan sehingga orang-orang dan pendidikan Islam dapat mengalami pertumbuhan, kemajuan, dan kembali ke kemakmurannya. Dalam hal ini, konsep segitiga Hadhariyah dapat digunakan sebagai pemecahan masalah alternatif untuk pendidikan Islam, dan membawa segitiga hadhara; mereka adalah hadhara al-nash, hadara al-'ilm, dan hadara al-filsafat. Untuk mengatasi krisis dan stagnasi dalam pendidikan Islam, perlu dilakukan peninjauan ulang reformasi pendidikan teologis filosofis, 
epistemologis, dan aksiologi, untuk mewujudkan pendidikan Islam sesuai dengan petunjuk wahyu.

Oleh karena itu, Muslim harus menerapkan pendidikan Islam berdasarkan fondasi ontologis, epistemologis dan aksiologis mengenai landasan Al Qur'an dan Sunnah. Al-Syaibany mengatakan bahwa seseorang yang mempelajari Islam di sumber Alquran dan Hadis dengan kesadaran yang mendalam akan melepaskan hasil pikiran universal tentang sesuatu, apakah filsafat menjadi, pengetahuan, dan atau filosofi nilai. ${ }^{3}$ Inilah yang akan dibutuhkan dalam pendidikan Islam. Sebagai salah satu upaya untuk meningkatkan pendidikan Islam, maka tulisan ini menyajikan konsep filsafat Hadhariyah. Ini termasuk: karakteristik filsafat Hadariyah, konsep pendidikan Islam berdasarkan filsafat Hadariyah, dampak positif pendidikan Islam berdasarkan filsafat Hadhariyah dan implikasi kurikulum integratif berdasarkan filsafat Hadhariyah.

Makalah ini disusun dan dianalisis dengan metode kualitatif deskriptif kritis. Sebelum penulis melakukan studi filsafat Hadhariyah, penulis pertama mengulas literatur yang berkaitan dengan filsafat Hadhariyah, dikotomi ilmu pengetahuan dan masalah pendidikan Islam. Para penulis kemudian melakukan diskusi tentang masalah pendidikan Islam dalam diskusi forum dengan menghadirkan pendekatan filosofis Hadhariyah sebagai solusi untuk dikotomi sains dan masalah pendidikan Islam.

\section{B. Pembahasan}

\section{KONSEP FILSAFAT HADHARIYAH}

Di Malaysia, istilah Hadhariyah terkenal dengan "Islam Hadhari" yang diperkenalkan oleh Dato 'Seri Abdullah Ahmad Badawi setelah dia disumpah sebagai Perdana Menteri Malaysia. Islam Hadhari bertujuan untuk menafsirkan nilai-nilai nyata dan bahan-bahan Islam dan sebagai 
kebutuhan pendekatan Islam dalam kehidupan sehari-hari Muslim Malaysia.

Secara etimologis, filsafat Hadhariyah terdiri dari dua kata, yaitu: "filsafat" dan "hadhariyah". Dalam hal semantik: kata filsafat berasal dari kata Arab, yaitu 'falsafah', yang berasal dari bahasa Yunani, 'philosophia', berarti 'philos' atau cinta, dan 'sophia' atau pengetahuan, kebijaksanaan. Jadi, 'philosophia' berarti cinta kebijaksanaan atau cinta untuk kebenaran. Dengan beberapa perubahan, dalam filsafat Indonesia disebut 'filsafat'. Di samping itu, kata Hadhari memiliki makna yang sama dengan civil urbanized, citified dan civilized, atau dengan kata lain yang disebut beradab. Selain itu, di Indonesia, kata 'peradaban' berarti kemajuan dalam aspek kecerdasan dan budaya. Jadi filsafat Hadhariyah adalah filsafat yang berdasarkan peradaban dan kemajuan.

Peradaban dalam hal ini adalah kemenangan peradaban yang dicontohkan Nabi, para filsuf dan ilmuwan Muslim pada abad 7-13 Masehi. Kemajuan di era Nabi Muhammad dapat dikategorikan dalam beberapa bidang, yaitu hukum, sistem sosial, ekonomi dan pendidikan, di mana Al Qur'an sebagai dasar dari semua sistem kehidupan ini. Di bidang hukum, misalnya, hukum rimba (rendah rimba untuk menjadi orang yang sopan), yang mengatakan siapa yang kuat maka dia akan menang, menjadi hukum yang menjamin hak-hak hidup manusia. Di bidang sosial, Nabi Muhammad berhasil menyatukan perbedaan di antara masyarakat dan mengubah konflik menjadi interaksi dan menekankan pelajaran-Nya tentang pengembangan karakter. Serta dalam pendidikan, menerapkan sifat populis pendidikan dengan membuat pengetahuan agama dan ilmu yang berguna sebagai bagian yang terintegrasi dalam proses pendidikan juga diterapkan di zaman Nabi. Dalam mendukung ini, Nabi mengirim teman-temannya untuk mempelajari manajemen Negara di Roma dan Yunani. 
Selanjutnya peradaban di era tengah (golden age), dengan lahirnya filsafat, sains dan teknologi, masjid dan perpustakaan menjadi pusat peradaban. Pada saat itu, Khalifah Harun Ar-Rasyid (786-809 M) mendirikan pusat untuk lembaga pendidikan (disebut 'Baitul Hikmah'), kemudian diikuti oleh Al Ma'mun, sebagai tempat untuk belajar ilmu agama dan ilmu umum (Kimia , Astronomi, Ilmu Kedokteran, terjemahan buku filsafat, sehingga mengarah pada kelahiran filsuf dan ilmuwan Muslim terkenal (seperti Al-Khwarizmi, Al Kindi, Al Razi, Al Farabi, Ibn Miskawaih, Ibnu Sina, Ibnu Bajjah, Ibn Rushd dan tokoh lainnya).

Berdasarkan penjelasan di atas, peradaban yang dicapai oleh Nabi dan dalam aspek-aspek baik-menengah dari hukum, sosial, agama, filsafat dan sains harus membimbing perkembangan masa depan peradaban. jelas ditunjukkan bahwa kemenangan diwujudkan karena membuat pengetahuan tentang Islam dan ilmu pengetahuan dalam posisi rekonsiliasi dan non-dikotomi.

Mengenai istilah peradaban yang dijelaskan sebelumnya, Assegaf menyatakan bahwa bidang studi Islam membagi pengetahuan menjadi tiga bagian, sebagai berikut;

i. Hadhara Al Nash : kemajuan peradaban yang berasal dari nash (agama).

ii. Hadhara Al-'ilm, yaitu kemajuan peradaban bersumber dari ilmu alam dan masyarakat (ilmu sosial).

iii. Hadhara Al-philosophy, yaitu kemajuan peradaban yang berasal dari etika dan filsafat. 4

Assegaf (2014, pp. 219-220) menambahkan bahwa Hadhariyah berfokus pada prinsip-prinsip integritas antara dimensi ketuhanan (teosentris) dengan kemanusiaan (antroposentrik), sesuatu yang berbeda secara diametral dari filsafat umum yang hanya didasarkan pada nilainilai manusia. Filsafat Hadhariyah mengakui yang nyata dan bersifat supernatural, fisik dan metafisis, sedangkan filsafat pada umumnya dibatasi oleh gejala yang dilihat dan ditangkap oleh indra. Filosofi dari 
Hadharia memandang pentingnya peran pewahyuan, dan nilai-nilai moral dalam pendidikan, sementara filsafat pada umumnya mengambil posisi sekularitas dan bersandar semuanya berdasarkan pada peran pikiran, akal, nilai-nilai budaya dan sosial. Filosofi al-hadhariyah menganggap bahwa pengetahuan belajar adalah untuk mencapai kesenangan Allah SWT (ilmu untuk Mardhatillah, thalab al-ilm li Mardhatillah), lebih dari sekedar ilmu pengetahuan untuk ilmu pengetahuan sebagaimana yang diinginkan oleh filsafat umum. Karena prinsip-prinsipnya berasal dari wahyu, maka Assegaf menyimpulkan bahwa filsafat al-hadhariyah penuh dengan nilai (nilai-ikatan) dan tidak bebas-nilai.

Selain itu, Hussain menguraikan 10 prinsip tentang Islam Hadhari yang disampaikan oleh Abdullah Badawi; mereka adalah iman dan kesetiaan kepada Tuhan, kerajaan adil dan dapat dipercaya, masyarakat berjiwa bebas, penguasaan ilmu pengetahuan, pengembangan ekonomi yang seimbang dan komprehensif, kehidupan yang berkualitas, pertahanan minoritas dan hak perempuan, integritas budaya dan moral, alam reservasi dan kekuatan pertahanan. ${ }^{5}$ Prinsip-prinsip itu sejalan dengan nilai-nilai Islam. Berdasarkan uraian di atas, para penulis menyimpulkan bahwa filsafat Hadhariyah adalah pandangan universal dari sebuah objek yang secara ontologis bergantung pada kombinasi dimensi ilahi, alam dan manusia, yang juga mengakui sifat realitas dan alam ide (fisik dan metafisik).

Secara epistemologis, filsafat Hadhariyah didasarkan pada kebenaran dan ilham wahyu filsafat pada masa Nabi-dan Chaliph rashidun dan pada puncak daullah Islam Abbasiyah, yang menjadikan wilayah penyataan dan wilayah pada dimensi akal terpadu. Sementara itu, aspek aksiologi filsafat Hadhariyah dalam memperoleh pengetahuan harus ditujukan untuk mendapatkan rahmat dan kesenangan Allah dan berharga bagi sosial dan peradaban. 


\section{KARAKTERISTIK FILSAFAT HADHARIYAH}

Salah satu karakter filsafat Hadhariyah adalah untuk mengintegrasikan wahyu Tuhan dan akal manusia. Dalam hal ini, penggunaan teorema naqliyah dan aqliyah menjadi sangat penting. Upaya untuk mendamaikan 'akal' dengan teorema naqliyah dan aqliyah yang diarahkan pada sains dan teknologi sebagai fondasi filosofi Islam Islam dan pengembangan metodologis filsafat pendidikan Islam. Hal ini dimaksudkan untuk membuat Islam mampu atau memberdayakan untuk masuk ke dalam gerakan ekonomi dan politik sentral, bukan Islam sebagai objek, tetapi harus dilemparkan. Di bawah ini menyajikan perbedaan antara filsafat umum dan filsafat al-Hadhariyah yang didasarkan pada wahyu. ${ }^{6}$

Tabel 1. Karakteristik Filsafat Hadhariyah dan Filsafat Umum

\begin{tabular}{|c|l|l|}
\hline No. & \multicolumn{1}{|c|}{$\begin{array}{c}\text { Filsafat Umum } \\
\text { (Perspektif Barat) }\end{array}$} & \multicolumn{1}{|c|}{$\begin{array}{c}\text { Filsafat Hadhariyah } \\
\text { (Perspektif Islam) }\end{array}$} \\
\hline 1 & $\begin{array}{l}\text { Anthroposentris (Dalam } \\
\text { konsep dan teori, tidak ada } \\
\text { hubungannya dengan wahyu } \\
\text { / agama) }\end{array}$ & $\begin{array}{l}\text { Theo-Anthroposentris (konsep dan } \\
\text { teorinya mengintegrasikan indera } \\
\text { manusia dan wahyu Tuhan) }\end{array}$ \\
\hline 2 & $\begin{array}{l}\text { Positivistik-empiris (Hanya } \\
\text { mengakui sesuatu sesuai } \\
\text { dengan gejala yang muncul) }\end{array}$ & $\begin{array}{l}\text { Transsendental dan } \\
\text { keberadaan alam nyata dan } \\
\text { supernatural) }\end{array}$ \\
\hline 3 & $\begin{array}{l}\text { Sekuler (menegaskan dimensi } \\
\text { keilahian dan konsep akhirat, } \\
\text { dan bahwa pendidikan } \\
\text { didasarkan pada rasio, nilai } \\
\text { budaya dan sosial) }\end{array}$ & $\begin{array}{l}\text { Non-Sekularis (itu menegaskan } \\
\text { dimensi keilahian dan konsep } \\
\text { akhirat, dan pentingnya moral dan } \\
\text { agama dalam pendidikan) }\end{array}$ \\
\hline 4 & $\begin{array}{l}\text { Berakar dalam rasio dan } \\
\text { budaya }\end{array}$ & Berakar dalam rasio, budaya, dan \\
wahyu
\end{tabular}




\begin{tabular}{|c|l|l|}
\hline 5 & $\begin{array}{l}\text { Etika pragmatis-hedonistik } \\
\text { (pengetahuan untuk sains) }\end{array}$ & Sains untuk Mardhatillah (Tuhan) \\
\hline 6 & $\begin{array}{l}\text { Mempertimbangkan interaksi } \\
\text { sosial }\end{array}$ & $\begin{array}{l}\text { Menggunakan integrasi vertikal } \\
\text { dan horizontal (Hablu minallah dan } \\
\text { Hablum Minannas) }\end{array}$ \\
\hline 7 & $\begin{array}{l}\text { Reward dan punishment hanya } \\
\text { diberikan di dunia. }\end{array}$ & $\begin{array}{l}\text { Pahala dan dosa diterima di dunia } \\
\text { dan akhirat. }\end{array}$ \\
\hline 8 & $\begin{array}{l}\text { Rasio dan skeptis adalah } \\
\text { berbasis pemikiran fisik. }\end{array}$ & $\begin{array}{l}\text { Pikiran modal } \\
\text { menggunakan } \\
\text { (keyakinan), hati (hati nurani) dan } \\
\text { rasio. }\end{array}$ \\
\hline 9 & $\begin{array}{l}\text { Pengetahuan dasar adalah } \\
\text { bebas-nilai. }\end{array}$ & $\begin{array}{l}\text { Menggunakan pengetahuan dasar } \\
\text { nilai-ikatan dan humanistik. }\end{array}$ \\
\hline
\end{tabular}

Berdasarkan uraian di atas, jelas ditunjukkan perbedaan antara dua pandangan realitas; mereka berasal dari yayasan ontologis, epistemologis, dan aksiologi.

\section{KONSEP PENDIDIKAN ISLAM FILSAFAT HADHARIYAH}

Filosofi pendidikan Islam harus diarahkan pada hal-hal yang mendasar dan mengarah pada pembentukan peradaban Islam, tidak hanya fokus pada aspek pendidikan normatif Islam. Berkaitan dengan ciri-ciri filsafat Hadhariyah di atas, maka pendidikan Hadhari menganggap perlu untuk meletakkan etika Islam yang bersumber dari nilai-nilai Al Qur'an dan Al Hadits. Selain itu, ia menjiwai seluruh deskripsi pekerjaan sains. Karakteristik Hadhari bukanlah dikotomi tanpa membedakan kelas, ras, etnis, bangsa dan atau agama. 
Sebelum penulis menggambarkan konsep pendidikan Islam berdasarkan filsafat Hadhariyah. Para penulis menolak pemahaman tentang pendidikan Islam menurut angka-angka pendidikan Islam. Menurut Qardawi dalam Langgulung (1980), pendidikan Islam adalah pendidikan manusiawi, intelek dan hati, spiritual dan fisik, karakter dan keterampilan. Dia merumuskan bahwa: Pendidikan Islam adalah sebagai proses mempersiapkan generasi muda untuk mengisi peran, mentransfer pengetahuan dan nilai-nilai Islam yang selaras dengan fungsi manusia untuk amal di dunia dan menuai hasilnya di akhirat. ${ }^{7}$

Lebih lanjut, makna pendidikan Islam di atas mengandung wawasan dasar Islam yang berkaitan dengan signifikansi manusia dan ilmiah. Pertama, pria dalam perspektif Islam adalah makhluk paling mulia Tuhan. Ia terdiri dari tubuh dan jiwa yang masing-masing memiliki kebutuhan sendiri. Kedua, dalam pandangan Islam, Manusia adalah makhluk rasional, serta memiliki nafsu binatang. Ketiga, manusia memiliki semacam organ kognitif seperti hati (qalb), intelek (aql) dan kemampuan fisik, intelektual, pandangan spiritual, pengalaman dan kesadaran.

Oleh karena itu, dapat dirumuskan konsep pendidikan Islam bahwa pendidikan Islam dalam upaya untuk mengajar, membimbing, melatih, membimbing dan mendidik masyarakat agar manusia memiliki kekuatan iman, karakter dan kedalaman ilmu (baik studi agama maupun ilmu umum. ), bahwa manusia mendapatkan tempat yang tinggi sehingga ada Hadhari Muslim. Pendidikan Islam adalah cara paling efektif untuk melatih, membimbing, dan mengarahkan peserta didik untuk mengetahui bagaimana menerapkan nilai-nilai Islam.

Berdasarkan ciri-ciri filsafat Hadhariyah, dapat dijelaskan bahwa konsep filsafat Hadhariyah harus memuat poin iman, sains, dan moral. Pertama adalah dimensi Iman sebagai kekuatan keyakinan. Iman adalah 
kekuatan yang membantu manusia untuk memimpin kepercayaan mereka dalam realitas sosial yang pada akhirnya juga menuntun manusia pada nilai-nilai kebaikan. Demikian pula, iman adalah sebagai kekuatan pendorong untuk melakukan perbuatan baik, untuk menetapkan nilai sistem masyarakat biasa.Di sini, kepercayaan diri adalah sebagai kekuatan manusia untuk siap tunduk dan patuh kepada sunatullah dan seluruh ketentuan Sang Pencipta.

Dengan demikian, pendidikan menjadi alat pembentuk dan memperkuat potensi kepercayaan diri siswa. Kedua adalah dimensi hati yang merupakan pengembangan karakter. Berdasarkan filsafat Hadhariyah, pendidikan Islam diarahkan untuk membentuk karakter siswa. Seperti yang dijelaskan oleh Quthb bahwa seorang pria yang baik adalah seorang pria yang ingin mengatur pendidikan sehingga ia tampak harmoni dalam dirinya dalam bentuk perilaku, pikiran dan perasaan. ${ }^{8}$ Dan yang ketiga adalah dimensi sains (baik studi agama maupun sains umum). Baik ilmu fisik maupun metafisik berguna untuk memecahkan masalah alam semesta, dengan memperhatikan keteraturan alam semesta. Untuk menciptakan Hadhari yang mendidik (maju dan beradab). Formasi ketiga dari dimensi di atas akan mencapai tujuan pendidikan tertinggi Islam Hadhari sebagai kelahiran manusia (kualitas maju, komprehensif dan konsisten dan beradab).

Konsekuensi logis dari filsafat Hadhariyah adalah pendidikan Islam berdasarkan filsafat Hadhariyah. Pendidikan Hadhariyah sebagai bentuk pendidikan dan beradab yang didasarkan pada Al-Qur'an dan Sunnah. Substansi pendidikan menempatkan Islam sebagai aksiologi Islam sebagai payung sains secara keseluruhan. Ini bisa dipahami sebagai pendidikan holistik dengan menempatkan ilmu agama dan ilmu umum sebagai bagian yang terintegrasi dan non-dikotomi. Filsafat Hadhariyah memberikan orientasi bagi subjek dan objek pendidikan, untuk 
meningkatkan iman dan mengembangkan ilmu dengan akal (akal), aqliyah dan naqliyah. Oleh karena itu, karena filsafat adalah fondasi berdasarkan nilai-nilai Al-Qur'an, maka filsafat Hadhariyah mengandung delapan (8) dampak positif sebagai berikut:

i. Melaksanakan pendidikan tanpa diskriminasi yang disebut pendidikan kerakyatan.

ii. Mempromosikan paradigma naqliyah dan aqliyah penalaran untuk menghasilkan peserta didik yang ulama dan ilmiah. Kebenaran wahyu adalah sebagai dasar untuk mengembangkan ilmu pengetahuan dan sains.

iii. Mempromosikan Integrasi antara agama dan sains (Ilmu Pengetahuan Modern), dengan menghilangkan pemikiran dikotomi.

iv. Epistemologi platform Pendidikan Islam membutuhkan guru dan siswa untuk melakukan secara aktif dengan proses eksplorasi ilmu agama dan sains modern, untuk pengembangan potensi peserta didik.

v. Kurikulum bersifat integratif, non-dikotomi. Kurikulum dirancang dengan memperhatikan semua dimensi peserta didik baik dimensi iman dan Ilmu (seperti yang dijelaskan dalam Al Qur'an)

vi. Mengubah pendekatan pendidikan Islam tradisional menjadi pola interaktif dan tidak aktif di kalangan pendidik, peserta didik dan lingkungan belajar.

vii. Meningkatkan orientasi tujuan pendidikan tertinggi pendidikan Islam ke peradaban manusia dan kemajuan dan mendapatkan tempat tertinggi di dunia dan akhirat, dengan iman dan sains. 
viii. Mengubah budaya lingkungan dan akademik yang hanya berkaitan dengan pendidikan sains atau hanya sebagai pendidikan agama menjadi lingkungan agama dan ilmiah

\section{Kesimpulan}

Filsafat Fadhariyah adalah pandangan universal dari sebuah objek yang secara ontologis bergantung pada kombinasi dimensi ilahi, alam dan manusia. Ia juga mengakui sifat realitas dan alam ide (fisik dan metafisik). Filsafat Hadhariyah adalah sebagai instrumen yang mendorong Pendidikan Islam di pintu gerbang Hadhari (peradaban). Dalam hal pendidikan, ini berfokus pada aspek pengembangan potensi pikiran yang komprehensif dan konsisten, hati dan amal sesuai dengan firman Tuhan dan bahasa serta nabi dalam kemuliaan Islam selama lebih dari lima abad, sehingga untuk menciptakan kualitas hidup yang baik, bermakna dan signifikan.

Selanjutnya, berdasarkan filosofi, dapat dibuat konsep pendidikan Islam dalam upaya untuk mengajar, membimbing, melatih dan mendidik masyarakat sehingga manusia memiliki kekuatan iman, karakter dan kedalaman ilmu (baik studi agama maupun ilmu umum. ). Akhirnya orang mendapat tempat yang tinggi sehingga dapat menciptakan Hadhari manusia. Pendidikan Islam adalah cara paling efektif untuk melatih, membimbing, dan mengarahkan peserta didik untuk mengetahui dan mempraktekkan nilai-nilai Islam.

Strategi pengembangan kurikulum berdasarkan filosofi Hadhariyah yang saling berhubungan dan terintegrasi dapat diimplementasikan dengan dua (2) pendekatan mereka; pendekatan internal dan eksternal. Dalam pendekatan internal, pendidik mampu menghubungkan mata pelajaran yang terkait. Tujuan integrasi dan interkoneksi adalah untuk memberikan pemahaman dan pemahaman 
universal untuk subjek. Sementara itu, dalam pendekatan eksternal, pendidik mampu bersatu di antara subjek satu sama lain. Selain itu, pendidik adalah kurikulum inti yang mampu mengintegrasikan aspek sains dan agama. Karenanya, sains dan agama haruslah damai dan saling menyapa.

Penulis : Basinun, M.Pd adalah Dosen pada Fakultas Tarbiyah dan Tadris IAIN Bengkulu

\section{DAFTAR PUSTAKA}

Abdullah, A. (2009), Falsafah Kalam Di Era Postmodernisme, Yogyakarta: Pustaka Pelajar.

Abdullah, A. (2011), Studi Agama: Normativitas Atau Historis?. Yogyakarta: Pustaka Pelajar.

Al-Syaibany. (1979), Filsafat Pendidikan Islam, Jakarta: Bulan Bintang.

Assegaf, A. R. (2014), Filsafat Pendidikan Islam: Paradigm Baru Pendidikan Hadhari Berbasis Integrative-Interconnected, Jakarta: PT.Raja Grafindo Persada.

Azra,A. (1999), Pendidikan Islam Tradisi Islam Dan Modernisasi Menuju Millennium Baru, Jakarta: Logos Wacana Ilmu.

Langgulung, H. (1980), Beberapa pemikiran tentang pendidikan Islam. Bandung: Al Ma'arif.

Hussain, A. A. (2006), Islam Hadhari : Suatu Kesinambungan Dasar Penerapan Nilai-nilai Islam Selepas Era Tun Dr. Mahathir Mohammad, Rekayasa, 2.

Mas'ud, A. (2007), Menggagas Format Pendidikan Nondikotomik, Yogyakarta: Gama Media.

Quthb, M. (1993), Sistem Pendidikan Islam. Bandung: PT Al-Ma'rif. 
1 Abdullah, A, Studi Agama: Normativitas Atau Historis?. Yogyakarta: Pustaka Pelajar, 2011

2 Mas'ud, A, Menggagas Format Pendidikan Nondikotomik, Yogyakarta: Gama Media, 2007

3 Al-Syaibany. Filsafat Pendidikan Islam, Jakarta: Bulan Bintang, 1979

${ }^{4}$ Assegaf, A. R, Filsafat Pendidikan Islam: Paradigm Baru Pendidikan Hadhari Berbasis Integrative-Interconnected, Jakarta: PT.Raja Grafindo Persada, 2014

${ }^{5}$ Hussain, A, Islam Hadhari : Suatu Kesinambungan Dasar Penerapan Nilai-nilai Islam Selepas Era Tun Dr. Mahathir Mohammad, Rekayasa, 2, 2006

${ }^{6}$ Assegaf, A. R, Filsafat Pendidikan Islam: Paradigm Baru Pendidikan Hadhari Berbasis Integrative-Interconnected, Jakarta: PT.Raja Grafindo Persada, 2014

7 Langgulung, H, Beberapa Pemikiran tentang Pendidikan Islam. Bandung: Al Ma'arif, 1980

${ }^{8}$ Quthb, M., Sistem Pendidikan Islam. Bandung: PT Al-Ma'rif, 1993 